\title{
A VIOLÊNCIA COMO DESVIO SOCIAL: BASES GERAIS DA INTERPRETAÇÃO POSITIVISTA DURKHEIMIANA SOBRE A VIOLÊNCIA'
}

Elsio Lenardão

\section{Apresentação}

ste artigo resultou da preparação de um mini-curso desenvolvido ,unto ao laboratório de Ensino de Sociologia da Universidade Estadual de Londrina, voltado aos professores do ensino médio que ministram disciplinas de sociologia. O mini-curso baseava-se na exemplificação de alguns roteiros de apresentação da teoria positivista por mim utilizados nos cursos que ministro na graduação, com o objetivo de compartilhá-los com os professores presentes.

Nesta ocasião, propus uma maneira particular de se falar do positivismo durkheimiano, a partir do tema gerador "violência". Selecionei alguns artigos de jornais e de revistas (ver anexos) conhecidas que revelavam forte influência dos pressupostos teóricos desenvolvidos e defendidos pelo positivismo durkheimiano. Propus, por exemplo, que tais pequenos textos que tratam de um tema pertinente ao dia a dia dos nossos jovens, poderiam ser utilizados como veículo de motivação para iniciar a apresentação da teoria positivista, bem como ilustrar a presença influente de seus princípios, pressupostos e conceitos nas reflexões e debates contemporâneos.

No entanto, para que o professor secundarista fizesse uso desse roteiro de discussão sobre o positivismo seria imprescindível que se sentisse seguro quanto a própria familiaridade e conhecimento que tem sobre esta teoria. Pensando em contribuir para a instalação dessa précondição elaborei um texto para o professor que contém aquelas informações mínimas sobre a contribuição de Durkheim ao entendimento, 
ao menos nos seus aspectos gerais, da "questão da violência". Portanto, o texto que segue foi preparado como apoio ao professor subsidiando-o para a elaboração de aulas em que pretenda falar da contribuição da teoria positivista para a compreensão dos problemas sociais.

\section{A influência imediata do contexto histórico sobre a obra de Durkheim}

É interessante observar que a forma e o conteúdo da construção teórica de Durkheim (1858-1917) é uma tentativa de resposta imediata aos problemas que afligiam a sociedade francesa do final do século XIX ${ }^{2}$. Mas os problemas desta sociedade eram antes de tudo problemas que aparecem com a sociedade industrial capitalista e que continuam a acompanhá-la, garantindo às reflexões de Durkheim "importante atualidade".

E qual seria o quadro da sociedade Francesa do último quartel do século XIX e início do século XX, que tanto preocupava Durkheim acabando por direcionar definitivamente a trajetória de sua obra e as "questões" de que irá tratar? Até porque Durkheim parte do suposto de que a sociologia era "um saber para a ação" (Torre,1982, p.37).

O cenário onde se desenvolve a obra de Durkheim é o da França do período de transição do século XIX para o século XX, que poderia ser pensado no espaço de tempo que vai de 1870 até à I Guerra Mundial (1914-1918). A parte inicial desse período é marcada por dramas políticos consideráveis, resultados da desastrosa intervenção militar da França no México $(1862-1866)^{3}$, da derrota da França na guerra contra a Prússia $(1870)^{4}$, dos aguçados conflitos entre as classes populares e o governo, transformados em verdadeira guerra civil que culmina com a instalação de um governo comandado por trabalhadores na capital Paris, em março de 1871, conhecido como a Comuna de Paris5.

Marcam então o período: a superação da influência política das forças do Império (Aristocracia, da Igreja), a derrota e humilhação diante da Prússia; o terror diante da "barbárie vermelha"; sensação de incapacidade do novo governo republicano de dar soluções à "balbúrdia" na qual se encontrava o país.

Durkheim refere-se à situação sócio-econômica da França, no 
final da década de 80 do século XIX, como sendo um "estado de anomia" jurídica e moral" (Durkheim,1997, p.VI). Ou seja, um quadro social comprometido pela ineficácia e desatualização das leis e normas existentes e pela fraqueza das regras morais presentes, na orientação das condutas dos indivíduos e grupos sociais.

De acordo com Torre (1982) a saída encontrada pela burguesia francesa, foi a de buscar apoio de outras classes sociais, inicialmente até mesmo de frações das classes trabalhadoras, com o intuito de enfrentar o "caos" que se abatia sobre a França. Tal propósito passava, antes de tudo, pela consolidação do modelo político republicano, unificando a nação ao redor desse ideário político. Em suma, superar de vez a influência social e política do clérigo e minimizar o poder dos setores ligados ao campo.

Isso implicava numa "unificação moral" dos franceses em torno dos valores liberais, próprios das sociedades industriais, e na recusa do código moral, ainda em parte vigente, ligado à forte influência da Igreja Romana materializada nos clérigos, que compunham uma das classes dominantes até então.

A construção de tal unificação moral em torno do ideário republicano exigia de imediato, a codificação e explicitação desses novos valores $^{7}$, portanto reformas nas leis e códigos de conduta e, ao mesmo tempo, o estabelecimento de um sistema educacional que desse conta de difundir esse novo código moral. É como consequência dessas necessidades que nos primeiros anos de 1880 cria-se na França um sistema de educação primária obrigatório, gratuito e laico. Até então, a organização e sustentação da educação era prerrogativa da Igreja Romana. Por isso o laicismo aparece como medida de destaque. O código moral republicano é laico. Trata-se da edificação de "uma moral sem deus" (Torre, 1982, p.12).

O código proposto carregava "preceitos favoráveis ao progresso e à ciência. Um código racionalista, e isto em dois sentidos, pois aceita como axioma fundamental o respeito à autonomia individual e permite $o$ livre exame e a pública discussão de seus preceitos. Um código, por último, nacional em que se identifica Nação e República, no qual o ideário

\footnotetext{
* Tradução do autor (N. da C.E.)
} 
de $1789^{8}$ se ressalta, sem dúvida, como uma contribuição de tipo universal, porém também, e com maior ênfase, como um ideário especificamente Nacional" (Torre, 1982, p.12).

O acento na valorização da "Nação" aparece como medida essencial à recuperação moral de um país que acaba de ser humilhado pela derrota de Sedan. Os republicanos investem bastante nesta medida. Avaliam também que a derrota deu-se antes, de tudo, em razão do atraso intelectual da França se comparado com o desenvolvimento acadêmico e científico da Alemanha. Dizia-se que não tinha sido o exército, senão a universidade alemã a responsável pela derrota da França.

Deriva daí, o investimento num programa de "regeneração" da Nação que começava pela introdução da ciência em toda a rede de ensino, sendo essa iniciativa não somente "sinal de modernização, mas algo mais, como uma peremptória necessidade patriótica" (Torre, 1982, p.13) . A ciência ganha destaque no código moral republicano, convertendo-se num valor republicano por excelência.

Por certo, pretendem enfrentar o "obscurantismo eclesiástico", na conquista moral das crianças da França, chamadas a educarem-se a partir de uma "educação científica" e enfaticamente patriótica, pensada dentro da tarefa urgente de "regeneração intelectual e unificação moral" da combalida França.

A valorização política da "regeneração intelectual" do país implicará na entrada em cena da pequena burguesia, principalmente através da crescente importância dos intelectuais ligados a ela, com destaque para os professores envolvidos na "batalha educativa". Os professores universitários serão os que mais se destacarão, envolvendose profundamente no debate político que buscava saídas ao país. Durkheim é o exemplo mais eloqüente.

Na consideração sobre o "tempo" de Durkheim, merece mais atenção um dos nós graves que afetavam a "ordem" social na França nas últimas décadas do século XIX, que era a chamada "questão social", ou, em outros termos, "o moderno enfrentamento entre o trabalho e o capital". Tal enfrentamento acompanha a consolidação do capitalismo francês com a mudança do modelo econômico até então vigente. Daí em diante as

\footnotetext{
* Tradução do autor (N. da C.E.)
} 
crises já não serão resultados das oscilações nos preços dos produtos agrícolas, mas principalmente das crises setoriais da indústria. É o tempo da aplicação de "novas tecnologias [no qual] se começa a utilizar novas fontes energéticas (substituição do vapor pela eletricidade), criam-se os setores industriais mais dinâmicos nos anos seguintes (química, metalurgia, automobilístico, borracha), chega-se a uma maior concentração do trabalho (criação da grandes fábricas modernas) e com ela a conquista de uma maior produtividade e a introdução da organização científica do trabalho seguindo o modelo americano" (TORRE,1982: 14 - trad. nossa).

Essas mudanças no modo de organizar a produção provocam também profundas transformações sociais, com destaque para o crescimento da classe trabalhadora operária e das lutas protagonizadas por ela. $\mathrm{O}$ crescimento das greves operárias sinaliza bem tal transformação: "As greves crescem (em 1880 foram 190 greves e 110.000 grevistas; em 1906, 1309 greves e 440.000 grevistas (...), também cresce sua duração, sua eficácia (no período $1871-1913,56 \%$ das greves obtém êxito em suas reivindicações) e as desordens aumentam em tais situações" (Torre, 1982, p.15) .

Aparecem os grandes sindicatos e partidos políticos com clara definição de classe, como será o caso do surgimento do Partido Socialista da França em 1905, que divergirá e disputará a influência política com o movimento republicano que, do ponto de vista do compromisso de classe, é ligado aos interesses da burguesia e pequena burguesia urbanas.

O crescimento da força política ligada ao movimento operário colocava no quadro da luta política novas propostas que criticavam a limitação do programa republicano que restringia-se à reforma política $\mathrm{e}$ educacional anticlerical, apontando para um projeto de reforma econômico-social mais radical, inspirado nos ideais socialistas clássicos.

É neste quadro sócio-histórico que aparece e é construída a sociologia durkheimiana. Em seus primeiros escritos parece influenciada pelas idéias socialistas (Zeitlin,1973), mas aceita um tipo de socialismo idealista, acentuadamente reformador.

Logo firma um posicionamento alinhado com o projeto reformista liberal-republicano, orientando suas pesquisas e reflexões pelas "questões" postas pela crítica política republicana: "desordem" social

* Tradução do autor (N. da C.E.) 
derivada das modificações no modo de produção; necessidade de "regeneração intelectual e moral" da nação francesa. Daí a especificidade de seus temas de pesquisa: o papel da Divisão do Trabalho social na "integração" social; o papel do Estado e do direito na "ordenação" coletiva; a função da escola na "socialização" das crianças; a função da religião na promoção da "coesão" social.

\section{Positivismo: \\ A sociologia da ordem}

Há na obra durkheimiana alguns "faróis de ilha" que norteiam suas reflexões e que são chaves para a compreensão do sentido de suas reflexões. Um deles é a ênfase na preocupação com os problemas envolvidos na "integração social", na "coesão social", na "harmonia e ordem social". Durkheim se preocupa especialmente com os fatores/ fenômenos que envolvem a estabilidade, a manutenção da organização social. Para ele "a sociedade é, antes de mais nada, um sistema de relações que tende à manutenção da ordem estabelecida para a sua organização através do consenso" (Vila Nova, s/data).

Por isso muitos chamam sua sociologia de "sociologia da ordem". Ao contrário, por exemplo, a sociologia derivada da obra marxiana seria também conhecida como "sociologia do conflito", pela centralidade da luta de classes, logo, do conflito, nas suas explicações.

Um outro "farol" fundamental para a articulação do conjunto das reflexões de Durkheim é o que deriva do suposto com o qual raciocina quanto a suma importância da "comunhão de valores morais" para a coesão social, para a integração de vida grupal.Um ponto de partida crucial na sua sociologia é a idéia de que a "moral" (conjunto de valores, juízos direcionados à vida em comum) é o principal cimento da vida coletiva, é o amálgama que une os indivíduos à vida em grupo. Para Durkheim a moral aparece como o conjunto de juízos e princípios que traçam "um plano de conduta ideal para os homens" (Durkheim, 1975, p.96). Afirmando o papel da moral para a coesão social, ele insiste: “( ... ) a moral é o mínimo indispensável, o estritamente necessário, o pão cotidiano sem o qual as sociedades não podem viver" (Durkheim, 1997, p.16). 
Revelando a centralidade que ele reserva à "questão moral", observe-se a tônica de seus comentários sobre o "caos social" que atingia a sociedade francesa em sua época, na qual, para ele, imperava o "individualismo" e a "dispersão moral". Durkheim alertará para o fato de que para a sociedade francesa recuperar sua "unidade orgânica", sua "harmonia e consenso moral", seria preciso que os indivíduos voltassem a sentir a "massa moral que o envolve e o penetra, que a sinta sempre presente e ativa, e que este sentimento regule sempre a sua conduta, porque não basta que se inspire dela só de tempos a tempos em circunstâncias particularmente críticas" (Durkheim,1975, p.101-102).

Já em 1888, na aula inaugural de seu Curso de Ciência Social, Durkheim adiantava a seus alunos que a "moral é mesmo de todas as partes da sociologia a que de preferência nos atrai e sobre a qual, em primeiro lugar, nos vamos debruçar" (Durkheim, 1975, p.99).

A sociologia durkheimiana sustenta o suposto da centralidade da "questão moral" para a ordem social numa outra pré-noção que é crucial a sua teoria: trata-se da concepção sobre a natureza humana. Para Durkheim, o homem em seu "estado natural", quer dizer, livre do controle social, seria um ser egoísta, impulsivo, movido por desejos e paixões imediatas, numa analogia bastante conhecida, comportar-se-ia como um lobo, constituindo-se mesmo até numa ameaça aos outros homens. Além disso, o homem não teria em si mesmo mecanismos próprios de auto-controle, de auto-limitação e de regramento. Conforme Durkheim: "As paixões humanas só se detém diante de uma força moral que elas respeitam. Se qualquer autoridade desse gênero inexiste, é a lei do mais forte que reina e, latente ou agudo, o estado de guerra é necessariamente crônico" (1997, p.VII).

Ocorreria então que, para Durkheim, a possibilidade do homem, marcado naturalmente por estes traços de personalidade, chegar a viver em grupos, em comunidades, passaria pela necessidade de sujeição de seus "apetites egoístas" a uma "força moral" externa e coercitiva a eles, capaz de controlar, regular e oferecer certa solução aos conflitos que constrangiriam a "natureza humana" submetida à vida coletiva. Conflitos originados por sua vez, das dualidades às quais seriam submetidas a natureza humana: instinto/razão, egoísmo/ altruísmo, ser individual/ser social. 
Concordando com a solução já clássica que Hobbes havia dado à dificuldade da constituição do homem em ser social, Durkheim dirá que o homem aceita, portanto deliberadamente, subordinar-se a uma "força moral" externa a si mas que lhe dará garantias para sua nova forma de sobrevivência, agora em comunidades. Essa "força moral" externa, essa autoridade a qual se sujeitará, será a própria sociedade, colocada como melhor antídoto ao egoísmo individualista. A sociedade é aqui reconhecida na condição de autoridade moral e legal (Zeitlin,1973, p.272). À sociedade caberá, dessa forma, o papel moderador dos conflitos da natureza humana. O objetivo de toda sociedade é segundo Durkheim " (... ) suprimir ou, pelo menos, moderar a guerra entre os homens, subordinando a lei física do mais forte a uma mais alta" (Durkheim,1997, p.VII).

Dirá ele, que uma norma moral "não é apenas uma maneira hatitual de agir; é, antes de mais nada, "uma maneira de agir obrigatória", isto é, que escapa, em certa medida, do arbítrio individual. Ora, somente uma sociedade constituída desfruta da supremacia moral e material que é indispensável para impor a lei aos indivíduos; pois a única personalidade moral que está acima das personalidades particulares é a formada pela coletividade. Além disso, apenas ela tem a continuidade e, mesmo, a perenidade necessárias para manter a regra além das relações efêmeras que a encarnam cotidianamente" (Durkheim,1997, p.X).

Além disso, Durkheim insistirá no fato de que uma "regulamentação moral ou jurídica exprime, pois essencialmente, necessidades sociais que só a sociedade pode conhecer; ela repousa num estado de opinião, e toda opinião é coisa coletiva, produto de uma elaboração coletiva" (Durkheim,1997: X). Mas, anote-se, Durkheim lembra que tal regulação não exclui, por parte do homem, certa dose de sacrifício e sofrimento, ao se sujeitar ao controle e limitar suas paixões.

Mas como que a sociedade, esta entidade abstrata, poderá promover tal tarefa? Durkheim observa que a "integração social" derivará principalmente da comunhão de "ideais coletivos", que penetram nas consciências individuais, organizando-se aí de modo duradouro, e fixando-se também nas instituições sociais (família, direito, sistema educacional) e em outros fenômenos de base social como símbolos nacionais, costumes, etc. Serão esses ideais coletivos (valores, princípios, 
juízos, prescrições) que, se consensuais e efetivamente respeitados, garantirão uma adequada normatização à vida social. Ou seja, uma situação de vida coletiva onde seus membros comungam, aceitam consensualmente, um importante conjunto de valores, de normas regras de conduta e prescrições, na qual, portanto, o quadro seria de "ordem, estabilidade, harmonia e coesão social".

Este conjunto de valores, ideais coletivos, constituem-se em verdadeiras forças morais, respeitadas pelos indivíduos como sendo de caráter sagrado, onde o deus supremo é a própria sociedade, quer dizer, ela é a fonte divina de autoridade moral, até porque é ela a entidade que o protege e garante sua sobrevivência. Ele foi um grande defensor da possibilidade da moral social ser basicamente laica, sem vínculos com os céus. Posição bastante sensata para quem participava de um movimento político-ideológico anti-clerical, conforme explicação dada no início deste texto.

O conteúdo desses ideais coletivos será sempre selecionado conforme a sociedade e o tempo histórico referidos e, seus elementos, comporão aquele fenômeno social conceituado, como "consciência coletiva", que "traduz a idéia do seja o psiquismo social, ( ... ) aquela [consciência] formada pelas "idéias comuns que estão presentes em todas as consciências individuais de uma sociedade" (Meksenas, 1992, p.64). Tal conjunto de "idéias comuns", constitui a base para uma "consciência de sociedade", que não é simplesmente a consciência individual, mas que é social e geral; e condiciona a conduta, a ação, do indivíduo na sociedade.

A consciência coletiva transporta e difunde junto aos indivíduos de determinada sociedade os valores, as normas, as prescrições e os costumes que a sociedade espera sejam compartilhados pelos seus membros Nas Regras do Método Sociológico (1966, p.1-2), Durkheim cita inúmeros exemplos da influência, senão controle, que a consciência coletiva exerce sobre a ação do indivíduo: "Quando desempenho meus deveres de irmão, de esposo ou de cidadão, quando me desincumbo de encargos que contraí, pratico deveres que estão definidos fora de mim e de meus atos, no direito e nos costumes. ( ... ) Estamos pois, diante de maneiras de agir, de pensar e de sentir que apresentam a propriedade marcante de existir fora das consciências individuais". 
Durkheim anota que os diversos ideais (regras morais, deveres, etc) que a consciência coletiva divulga e que se associam à vida individual, ao fazê-lo individualizam-se, relacionando-se com outras representações e harmonizando-se com elas, com o temperamento, com o caráter, com os hábitos do indivíduo, etc ... "Cada qual [indivíduo] os marca [os ideais, os valores] com o seu cunho próprio; é assim que cada um tem a sua maneira pessoal de pensar as crenças da sua igreja, as regras da moral comum, as noções fundamentais que servem de quadro ao pensamento conceitual". Não obstante, ele alerta para o fato de que a consciência coletiva não é o que o índivíduo pensa, mas o que a "sociedade pensa". Diz ele, que embora "sendo nossos, eles [os ideais sociais, coletivos] exprimem-se em nós num tom totalmente diferente do resto dos estados de consciência: ordenam-nos, impõem-nos o respeito, não nos sentimos no mesmo plano do que eles. Damo-nos conta de que eles representam em nós algo de superior a nós" (Durkheim,1975, p.301-302).

No caso da ênfase que Durkheim coloca sobre a "questão moral" tratando-a como o eixo explicador central dos fenômenos sociais, levao, por outro lado, a tratar a "questão social" (da luta de classes, justiça social, igualdade social) como secundária e subordinada à primeira.

Mesmo alertando em alguns textos sobre os perigos à "paz social" quando estão presentes graves "injustiças sociais" e fortes "hierarquias de status" (Durkheim, 1997, p.XXXIX), considera mesmo assim, que é possível garantir-se a "coesão e a ordem" em sociedades socialmente desiguais, se a "questão moral" for bem resolvida. Noutros termos, a "paz social" estará garantida se a sociedade, consensualmente, conseguir promover a formulação de um adequado conjunto de valores, transcrevêlos em normas, regras, prescrições, enfim na lei, e conseguir ainda, fazer valer essa lei, aplicá-la efetivamente. Isso até mesmo em sociedades marcadas por acentuados contrastes sócio-econômicos, recortadas por profundas diferenças entre as classes sociais, situações sempre materializadas em quadros sociais compostos pela convivência entre opulência e miséria, inclusão e exclusão, privilégios e abandono, satisfação e exploração, etc.

A sobrevalorização do elemento "moral" na estruturação das sociedades encontrado em Durkheim, já havia aparecido no fundador da sociologia Augusto Comte (1798-1857). Neste, a crença no poder da transformação dos valores chegou a levá-lo a elaborar "um esquema de 
uma religião da humanidade. Pensava ele que a pregação moral abrandaria os capitalistas e assim seriam mais humanos com os proletários e as mulheres, eliminando os conflitos de classes, mantendo porém, a propriedade privada" (Triviños, 1987, p.33). Durkheim, herdeiro desta tradição, manterá a atenção sobre a capacidade integrativa, coesional da moral.

Durkheim admitia claramente a existência de diferentes classes e estratos na nova sociedade industrial. Acreditava também, que as novas condições desta sociedade levariam a uma ordem hierárquica, porém orgânica, estável, caracterizada pela paz social e pela estabilidade. Já que, para ele uma sociedade é sobretudo "uma comunidade de idéias". Por isso, opõem-se a uma concepção de sociedade e de transformação social que se baseie nas classes e nos conflitos de classe. Propõe uma teoria que pensa a sociedade como baseada na solidariedade "orgânica"10, e que desconsidera as implicações reais da divisão da sociedade em classes sociais.

Diante destes pressupostos imagina a superação dos conflitos oriundos dos antagonismos de classe, através da "difusão efetiva de uma moral consensual". Explicita-se aqui que a existência de classes e estratos não exclui a unidade moral e a solidariedade geral. Tudo o que esse "sistema de funções", que é a sociedade, precisa para funcionar de maneira harmoniosa, é de uma regulação moral apropriada

\section{A história resolvida por leis}

Para Durkheim a entidade abstrata "sociedade", fonte da autoridade moral para o homem ser-social, deixa de ser algo intocável e invisível quando se estrutura em instituições, que lhe garantem materialidade e visibilidade: como seria o caso do aparecimento da família, da religião, do Estado, da lei, dos sistemas educacionais.

Dentre estas instituições o Estado, pensado como "aparelho governamental", (Durkheim,1997, p.103) seria a instituição que melhor objetifica a sociedade tendo assim maior responsabilidade na representação da vontade coletiva, na satisfação dos anseios gerais da coletividade. O que implica na crucial tarefa de promover aquela regulação moral apropriada, acima referida. 
Visto pela sociologia positivista como o "cérebro da vida social," cabe ao Estado a responsabilidade de recuperar a "unidade orgânica" da sociedade, desenvolver o funcionamento orgânico de todas suas partes e, especialmente, reelaborar aspectos da consciência coletiva que eventualmente estejam defasados, comprometidos. Ou, em termos durkheimianos, "criar a moral social", garantindo também que ela seja posta em prática. Compete-lhe enfim, "dirigir a conduta coletiva" (Durkheim, 1983, p.47).

Mas como transformar essas funções em ações concretas? A partir da idéia de que o amálgama que articula as relações sociais tornase possível, garantido, graças à presença do fenômeno da solidariedade, o Estado deveria estimular e regular o desenvolvimento deste mecanismo de interação social, particularmente a solidariedade de tipo orgânica, típica da sociedade industrial. A realização desta tarefa passaria principalmente, pela iniciativa em organizar os grupos profissionais em corporações, no caso em Associações, sindicatos, incentivando desse modo, a identidade grupal e a solidariedade nascida desta identidade. Durkheim apostava bastante neste tipo de associativismo também porque via que, na sociedade capitalista, as associações profissionais forjavam minuciosos códigos de conduta, códigos de ética profissionais, ${ }^{11}$ para a regulamentação das atividades profissionais de seus membros. Ele via aí, uma fonte fundamental de regulação da vida moral dos trabalhadores nestas sociedades. Por isso a sociedade, através do Estado, deveria atentar bastante para essas formas de Associação, já que elas ofereciam à sociedade um espaço e um momento de "enquadramento" da conduta do indivíduo, portanto, uma ótima chance para o controle social sobre ele.

É crendo nessa potencialidade das corporações que um dos principais remédios que Durkheim indica à "anarquia" que assola a França no final do século passado, é um "remédio moral": é a recuperação da corporação profissional, "por causa não dos serviços econômicos que ela poderia prestar, mas da influência moral que poderia ter". Porque, o "que vemos antes de mais nada no grupo profissional é um poder moral capaz de conter os egoísmos individuais, de manter no coração dos trabalhadores um sentimento mais vivo de sua solidariedade comum, de impedir que a lei do mais forte se aplique de maneira tão brutal nas relações industriais e comerciais"' (Durkheim, 1997, p.XVI). 
A noção de Estado vista no positivismo, que o apresenta como o órgão máximo, o representante global da sociedade, fundada no liberalismo pluralista, supõe algumas premissas: primeira, a de que o Estado e seus aparelhos (justiça, escola, burocracia) é um órgão politicamente sempre neutro, isto é, nunca está a serviço de nenhum fator de poder. Por consequência, como é neutro, é também independente e, portanto, em nenhuma ocasião serve aos interesses de grupos particulares de interesses ou grupos de influência numa sociedade. Em segundo lugar, todos os indivíduos são reconhecidos pelo Estado e seus aparelhos como virtualmente iguais em termos de seus esquemas valorativos, isto é, o Estado parte do princípio da homogeneidade moral no seio da sociedade que ele organiza, onde todos os indivíduos a despeito das suas diferenças de classe, posições diferentes na hierarquia, estariam comungando, ao menos, um conjunto unitário de valores, de ideais de referência, que apontariam para o Estado qual seria a "vontade geral" da coletividade ${ }^{12}$ (Torres, 1992).

Como a sociologia positivista preocupa-se, principalmente, com os fatores ligados à "ordem moral", com o "consenso moral", analisa com destaque a tarefa reservada ao Estado de intervir diretamente na promoção e indicação aos indivíduos de propostas de conduta moral. Por várias vezes Durkheim anotou que tais tarefas deveriam ser realizadas através: a) da "educação moral", intervindo no sistema educacional, onde o ensino chega a adquirir "o papel de cimento que solda a diversidade das partes e até eliminará os conflitos sociais" (Ortiz, 1989, p.7). Esta intervenção deve ser atenta ao papel da educação como socializadora das gerações mais novas por onde elas terão contato com os valores e juízos de sua coletividade, norteadores básicos para seu futuro de adulto ligado organicamente à vida coletiva. E, b) do cuidado na formulação, reformulação e ajustamento permanente das leis, corrigindo os casos patológicos da sociedade, evitando as situações de anomia.

A lei nesta sociologia é vista quase que como um bálsamo milagroso capaz de curar as "feridas" sociais (violência, conflitos sociais de toda ordem, inclusive os de classe), e restaurar o "bom convívio", a paz social. A "boa lei", quer dizer, aquela que é minuciosa, que reflete anseios da "vontade geral" da sociedade, que é atualizada e que recebe garantias do Estado de que será exigido seu cumprimento, é um 
instrumento poderosíssimo de que dispõe a sociedade para direcionar condutas coletivas, para corrigir desvios de comportamento, etc.

Por exemplo: na compreensão positivista do fenômeno da criminalidade, crê-se que, se ela aumenta a cada dia, se assume proporções que comprometem a vida social, é porque, primeiro, há falhas nas regras de conduta, nos valores morais com os quais os indivíduos vêm organizando suas condutas. Há então um problema de "ordem moral", que precisa ser corrigido. E, em segundo lugar, porque as leis e os órgãos que regulamentam o combate ao crime estão falhando, ou, por serem as leis mal formuladas ou pelo fato do Estado não conseguir aplicá-las.

\section{Notas}

Texto apresentado no "Encontro do Laboratório de Ensino de Sociologia", promovido pelo Departamento de Ciências Sociais da UEL.

${ }^{2}$ Ver: BRESCIANI (1990)

3 "Entre 1862 e 1867, Bonaparte [Luiz Napoleão Bonaparte] interveio no México, numa guerra que arruinou as finanças francesas. Com o objetivo de garantir o comércio francês na América, conter a crescente hegemonia norte-americana e pôr fim à instabilidade política entre grupos locais, as tropas francesas invadiram o México, derrubando seu presidente Benito Juarez. Entretanto, os problemas financeiros e militares e a instabilidade política e militar na Europa fizeram com que Napoleão III retirasse suas tropas do México em 1866". (Vicentino, 1991, p.223).

${ }^{4}$ A França envolveu-se numa guerra contra a Prússia que passava por um processo de unificação territorial/Nacional, dirigido por Bismarck, e que resultaria na criação do Estado Alemão, em 1870.

"Os prussianos venceram a França, e o próprio Napoleão III foi feito prisioneiro na Batalha de Sedan, em 1870. A derrota francesa teve duas consequências imediatas: acabou o segundo Império [1852 - 1870], que deu lugar, em setembro de 1870 , a Terceira República, e permitiu a concretização da unificação alemã. À França coube, pelo Tratado de Frankfurt, entregar à Alemanha suas ricas regiões em minérios - Alsácia e Lorena -, pagar uma pesada indenização, além de aceitar que a festa oficial de criação do novo Estado Alemão fosse realizada no palácio de Versalhes [nos arredores de París] ( ... ). A derrota francesa em Sedan diante dos prussianos instalou o colapso político na França. A humilhação sofrida pelo país aguçou os conflitos entre as classes sociais e os grupos políticos, colocando os populares parisienses contra o governo republicano em Versalhes, sob a presidência de Adolphe Thiers. $O$ auge dos conflitos deu-se com a proclamação de um governo autônomo na capital, em março de 1871, a Comuna". (Vicentino, 1991, p.223) A "Comuna" (março a maio de 1871) resultou da tomada do governo de París por parte dos membros dos movimentos políticos radicais franceses, com poderoso 
apoio popular. Destituiram os dirigentes da cidade e instalaram ali a primeira experiência histórica de autogestão democrática e popular, com forte inspiração socialista. Os trabalhadores organizados em assembléias bastante frequentes reorganizaram a vida da cidade direcionando suas atividades à satisfação das necessidades dos indivíduos das classes trabalhadoras. A experiência durou apenas setenta e dois dias. O governo Republicano, que acabara de ser instalado reagiu violentamente à ousadia dos trabalhadores. Os soldados franceses invadiram a cidade para retomá-la para os seus antigos "donos": comerciantes, banqueiros e clérigos. O exército francês matou mais de vinte mil trabalhadores que resistiam à entrega da cidade. Outros setenta mil teriam sido exilados e deportados para a Guiana Francesa (VICENTINO, 1991: 223-224).

"O conceito de "anomia" em Durkheim, trata das situações da vida social que se encontram marcadas pela "ausência de regras e prescrições bem definidas e materializadas" em lei, ou pela presença de leis e normas defasadas, ultrapassadas pelo tempo, de maneira que não fica definido com clareza como os agentes sociais devem se comportar nestas situações. Conforme seus termos a "anomia é um mal", já que a sociedade não pode "dispensar, para viver, a coesão e a regularidade", só garantidas pela definição clara das normas e indicações das condutas.

${ }^{7}$ Especialmente valores de base laica, sustentados na tradição iluminista e na crença otimista dos poderes da ciência.

8

Refere-se à Revolução Francesa...

${ }^{9}$ Observe-se a descrição clara que Durkheim dá sobre o conteúdo da "consciência coletiva": "Há em toda a sociedade um certo número de idéias e de sentimentos comuns que as gerações transmitem umas as outras e que asseguram, ao mesmo tempo, a unidade e a continuidade da vida coletiva. Tais são as lendas populares, as tradições religiosas, as crenças políticas, a linguagem, etc". Compõem-se também de um conjunto de "juízos", admitidos pela generalidade dos cidadãos, e que visam orientar suas ações práticas e além disso, são obrigatórios. "Exercem uma espécie de ascendente sobre as vontades, que se sentem como que coagidas a conformarse-lhes". Tais "juízos", formam um conjunto de "princípios" de conduta que constitui a "moral" (Durkheim,1975, p.95-96).

${ }^{10}$ Para Durkheim, a acentuação da divisão social do trabalho nas sociedades industriais modernas, acabou por criar uma espécie de interdependência entre os indivíduos que, tornada consciente, reconhecida, é justificativa bastante forte para o desenvolvimento da solidariedade social. Um exemplo sempre citado que ilustra esse fenômeno é o caso do padeiro, de quem tanto se precisa $E$ que, por sua vez depende de um número incontável de outros profissionais para realizar sua tarefa, criando uma rede de interdependência pela divisão do trabalho. A acentuação da especialização das atividades profissionais gera também outros fenômenos valorizados por Durkheim em razão de serem fenômenos promotores de "regras morais". Ele acreditava que o agrupamento dos indivíduos por ofícios - metalúrgicos, marceneiros, médicos, advogados, professores - e o desenvolvimento e fortalecimento de suas Associações e Sindicatos, terminava por gerar novos espaços de promoção de "regras de conduta", de "regras morais". Isso seria possível porque as entidades profissionais elaboram códigos de conduta profissional - os famosos 
códigos de ética, regimentos, etc. -, regulando o dia-a-dia de seus profissionais, enfim, definindo orientações de conduta, normalmente conforme as regras morais gerais da sociedade envolta. Seriam, portanto, entidades que cumpririam também o papel de "regradoras morais" das relações entre os membros dos ofícios e entre estes e os demais indivíduos. As Associações profissionais são, segundo Durkheim, importantes fontes de corpos de regras morais (Durkheim, 1997, p.XXI). As normas de conduta que tais Associações produzem são "forças morais" com papel fundamental na sustentação da solidariedade das sociedades modernas, a qual Durkheim chama de "solidariedade orgânica". A solidariedade social nasce ainda de laços que a tradição, a semelhança étnica, a religião e o parentesco promovem; elementos que em outros tempos históricos tiveram preponderância. As proximidades geradas por estes laços são chamados por Durkheim de "solidariedade mecânica".

"Trata-se, por exemplo, dos atuais códigos de ética profissionais como: código de ética médica, código da $\mathrm{OAB}$, os regimentos das diversas profissões, etc..

${ }^{12}$ Esta noção de Estado é ainda hoje a mais comum, aceita e divulgada. Veja, nos anexos, exemplos de sua presença.

\section{Referências Bibliográficas}

BRESCIANI, maria Stella M. Londres e Paris no século XIX: o espetáculo da pobreza. São Paulo, Brasiliense, 1990.

DURKHEIM, Emílio. Curso de Ciência Social: In: A ciência social e a ação. São Paulo, Difel, 1975.

DURKHEIM, Emílio. As regras do método sociológico. São Paulo, Cia Editora Nacional, 1966.

DURKHEIM, Emílio. Divisão do trabalho social. Martins, Fontes, Lisboa, 1997.

DURKHEIM, Emílio. Lições de sociologia: a moral, o direito e o Estado. T.A. Queiroz/Universidade de São Paulo, São Paulo, 1983.

MEKSENAS, Paulo. Aprendendo sociologia: a paixão de conhecer a vida. São Paulo, Loyola, 1994.

ORTIZ, Renato. Durkheim: arquiteto e herói fundador. Revista brasileira de ciências sociais. $\mathrm{N}^{\circ} 11$, Vol. 4, 1989.

TORRE, Ramón Ramos.Introdução. In: Durkheim, Emílio. El socialismo. Madrid, Ed. Nacional, 1982.

TORRES, Carlos Alberto. Sociologia política da educação. São Paulo, Cortez, 1992. 
TRIVINÕS, Augusto N. S. Introdução à pesquisa em ciências sociais. São Paulo, Atlas, 1987.

VICENTINO, Cláudio. História Geral, São Paulo, Scipione, 1991.

VILA NOVA, Sebastião. Introdução à sociologia. s/data. (mimeo)

ZEITLIN, Irving. Ideologia y teoria sociológica. Buenos Aires. Amorrortu editores, 1973.

\section{Resumo}

$\mathrm{O}$ artigo organiza aspectos gerais do positivismo durkheimiano, num roteiro de apresentação que visa facilitar a forma como tal teoria entende o fenômeno da violência nas sociedades modernas. Para tanto, começa explorando o contexto histórico que cerca o trabalho intelectual de Durkheim revelando a influência imediata deste contexto sobre sua obra. Em seguida, destaca a atenção que o autor dá à questão da 'ordem social' e, por último, comenta sua concepção de história, na qual 'as leis' desempenham um papel essencial. O artigo foi escrito como subsídio material aos professores da rede estadual de ensino que ministram a disciplina de sociologia no $2^{\circ}$ grau, atendidos pelo Laboratório de Ensino de Sociologia da Universidade Estadual de Londrina.

Palavras-chave: positivismo; Durkheim; ensino de sociologia.

\section{Abstract}

This article organises general aspects of Durkheimian positivism in a course of presentation that aims to facilitate the manner as such a theory comprehends the phenomenon of the violence in the modern societies. This article starts exploring the historical context that surrounds the Durkheim's intellectual work, revealing the immediate influence of this context under his work. Next, it shows up the attention that the author gives to the 'question' of the 'social order', and, last it comments Durkheim's conception of history, in which 'the laws' discharge an essential role. This article was written as a material of subside to the teachers of the State Net of Teaching that administer the discipline of Sociology in the high school, ministered by Laboratory of Teaching of Sociology of Universidade Estadual de Londrina.

Key-words: positivism; Durkheim; sociology teaching.

Elsio Lenardão

é professor de Sociologia do Departamento de Ciências Sociais da UEL

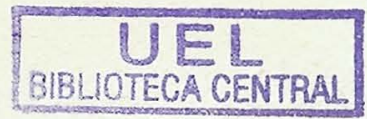




\section{Anexos}

\section{Gazeta do Povo - 01/05/2000}

Causas do
latrocínio:
consumo
de drogas
e certeza de
impunidade,
ou seja, a lei
não funciona

Outra causas
do problema:
de raiz
cultural;
cultura do
individualismo

\section{Recado de um crime}

Carlos Alberto di Franco

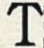

overns de classe média foram brutalmente assassinados em uma casa de praia no litorai sul de São Paulo. Os corpos foram encantrados com os pés e os braços amarrados com cordas de nálion e apresen tavam sinais de tortura. Facas e espetos de churrasco foram as amas utilizadas pelos as sassinos. A crueldade fol completada com a queima de un dos corpos. No momento em que escrevo este artigo, dois assassinos foram presos. Consumo de drogas e certeza da im puaidade foram as causas do Latrocinio. 0 crime, nio obstante sua extrema perversidade, năo produzin o mesmo impacto que causaria no passado. Tratou-se, na verdade, de mais um. Um registro excessivamente rotineiro um. Um registro excessivamente rotineiro ma crônica policjal de uma sociedade sem alma. Ele ocupou, talvez, o teinpo de uma conversa de barbearia. E nada mais. E duro, sobretudo Estamos, todos, perigosamente anestesiados pela cáncer da violéncia que vai minando o orgela cancer da

Paira no ar a mesma pergunta que Pairu no ar a mesma pergunta que
Fellini pós na boca de um dos personagens Fellini pós na boca de un dos personagens
do seu filmı Ensajo de Orquestra, quando, do seu filme Ensajo de Orquestra, quando músicos depois da destituiçáo do maestro, perguntava, perplexo: "Como é que che gaunos a isto?" A interrogacão esta subjacente em inumeras cartas de leitores que. atordoados, tentam encontrar resposta para a escalada de maldade que invadiu o cotidiano.

Velhas e reiteradas hipoteses, esgrimidas há alguns anos, nâo convencem mais. E difícil acreditar que apenas diferenças sociais, niveis de pobreza ou quaisquer explicaçóes exchusivamente sociocconômicas sejam stuficientes para explicar o fenómeno. Para tentar enten der a ro desa patologia social, perturbadora e surpreendente, reli un iuteressante ensaio do professor Francis Fukizyama. Em A grande professor Francis Fiukizyama. Em A grande ruptura, texto publicado na revista Atlantic Fukuyama atribui o aumento da violência "cultura do individualismo". Segundo ele, mesma sociedade que rảo admite limites er sua inovação tecnológica (basta pensar nas consequéncias anti.lłumanas que se vislum. consequências anti-łumanas que se vislum bém "não percebe os limites em muitas for mas de comportamento pessoal, e a conseqüència é o aumento do crime, familias des. feitas, o malogro dos pais em exigir obri gaçées dos filhos, a recusa do vizinho de ter responsabilidade pelo outro e a retirada dos cidadãos da vida pública"

Há, de fato, no cenne do problema, uma pro funda raiz cultural. Na verdade, as bases racionais da modernidade foram minadas pe. lo pensamento de Nietszche. O pai do rela. tivismo modemo sempre argumentou que o tivismo modemo sempre argumentou que o que a complexa "linguagem do bem e do mal" manifestada pelas diferentes culturas eram manilestada pelas diferentes cuituras eram puros produtos da vontade humana, independentemente da verdade ou da razäo. Rompen. se, assim, o nexo de uniào entre vontade $e$ razăo. Dessa forma, as pessoas passaram a confundir gosto com vontade, sem consegui cantar as profunda vez mais o gosto, 0 capricho, o prazer (incluindo as suas manifestaçóes mórbidas e patológicas) passatam a impor a sua força cega

Na verdade, um dos traços comporta mentais que marcam a crescente decom. posiçáo ética da sociedade é o desapareci. mento da noção da existência de relaçảo entre causa e efeito. A responsabilidade. consequência direta e imediata dos atos humanos, simplesmente evaporou. Além disso, quando toda uma geraçáo é educada nas telas dos computadores e no espaç virtual, onde tudo, rigorosamente tudo, es tá ao alcance da mão lou da fantasia): quando nảo é preciso lazer nenhum eslorço para conseguir as coisas; quando náo exis tem distáncias nem intermediários entre 0 desejo e sua satisfaçào imediata; quando o delito é absolvido pelo manto protetor da impunidade, a violencia passa a ser um jogo, um macabro passatempo.

A sociedade precisa de um choque de A sociedade precisa de um choque de bom senso. limpoese a recuperaçáo da nocáa da exastencia de relaça entre causa e eleito. O erro. independentenente dos ar. gumentos da psicologia da irresponsabili. dade, deve ser condenado e punido, 0 mal existe $e$, sem dúvida, tem algo de insondável. Mas a crueldade nảo é fruto do acaso. Ela cresce no terreno fértilizado pela omissáo. 0 resultado final da pedagogia da concessáo da crise da autoridade está apresentando dos a bora de lalar clara. E preciso por o de. do na chaga $e$ identificar a relação que existe entre o medo de punir e os seus eleitos antisociais.

- Carlos Alazrto Di Funaco, drestoe do

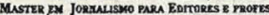
SOR DE ETACA JODEALLSTACA, E REPEESETEATTE DA

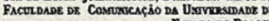

Crescimento da violência associado ao desprezo pela razão, à vigência do gosto, da vontade, do capricho e do individualismo.

Solução?: "choque de bom senso", mudanca na consiciência e no funcionamento da lei.

O autor vê a sociedade como "organismo social". Logo, a violência como um câncer que o mima, ou seja, algo que é como um adendo, um problema que deve ser estirpado, curado, para o organismo social voltar à sua "normalidade". Como é tratado como doença, implica em considerá-la como eventualidade. Causa?: "Cultura do individualismo" / desconcientização pela necessidade de limites ao comportamento. Portanto, o crescimento da criminalidade estaria bastante ligado à "questão moral", do regramento soclal do comportamento. 


\section{Jornal da TFP - 24/04/1996}

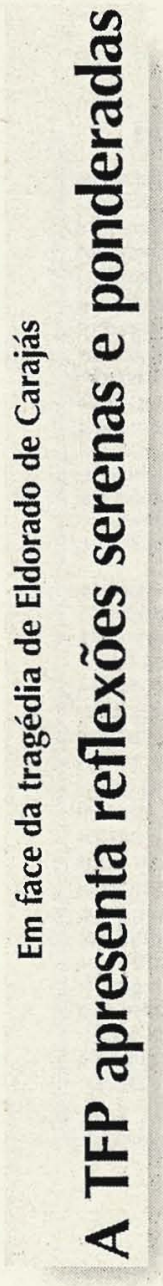

A opiniāo nacional recebeu com sums consternação e perplexidade a noticia da tragédia ocorrida em Eldorado de Carajás, no Pará, onde integrantes do MST, que bloqueavam importante rodovia, enfrentaram a Policia uxcumbida da missáa de restabelecer a ordem no local

Consternação porque nosso bom povo aborrece desavensas e desamonius. sobretudo quando elas desfecham em inortes: eom efcito a coracào bra sileiro sangra quando vé a concórdia ceder lugar à violencia e a benquerença ser substituida pelo adia.

Perplexidade porque, intuitivo com $c$ nossa povo, naw the agrada que essa Iragédia seja noticiada numz estado cmocinnal que sn pode favorecer os pescado. res de águas furvas.

Sobretudo não é de boa tei, nnm cli ma altancente aquecido e mesmo apaixo nado, tomar medidas de suma gravidade, comn seria um aptessamento radicalizaço da Reforma Agrária socialista e confiscatória, em relaçào à qual a opiniào pública vai se sentindo cada vez mais distante e desconfiadit.

A TFP, partillando essa consternaç̄o o essa perplexidade, apresenta is sutoridades e as piblico refiexôes surenas e ponderadas sobre aspectos fundamentais dessa tragédia. Com isso, deseja cla eontribuir para satisfazer os melhor: anseios de nosso povo, tào sofrido, mas tumbim tio ordeiro, cardato e descjoso de verdadeira paz.

- Reflexỏes serenas e nonderadas cram a característica constante de nosso Fundador, o muito saudoso Prof, Plinio Corréa de Oliveira. Evoctindo seus ensinamentos a seguindo seu exemplo, inciamos estas consideracrues corin os olhos posios no Sagrado C c a aciáo de Jesus e no inaculài . saçio de Maria Esperamos assim cac, pam mellow servir o Brasil, nossas reflexóes tenham o equilibrio e a força que marcaram os pronunciamentos daquele a quien a TFP deve sua fundacio e que the serve de modelos constante inspicaçio

1. O MST nos caminhos da

guerrilha: a tragédia

inteiramente previsive

Lastimavelmente, o MST de há muito $\mathrm{vem}$ se lancando pelos caminhos do desafio $₹$ da guerrilha. Quanio mais se the concele, mas exige e mais se arma.

Habituados a que, diante deles, as autoridades peralmente cedem e a midia as promove, os líderes do MST vêm se tormandn cada vez mais arrogantes na escalada da violéncia, com vistas à to. mada do Poder, objetivo expressamente consignado em seus docuntentos oficiais.

No Documento Básico do MST, apro- 


\section{Folha de Londrina - $s$ data}

\section{Bom texto para iniciar uma discussão sobre a importância das regras morais e em seguida da relação do indivíduo - sociedade, introduzindo o debate de Durkheim}

\section{Moral, ético e legal}

$O$ homem è un ser que precisa viver cili sociedade. Querendo ou não, vive dependendo da politica e necessariamente vive u mundo económico: é o homem um ser social, politico e econômico. Contudo. o que conduz o homem a viver uma vida digna de ser hurnano e a ordem mo. ral: cada um deve viver dentro do costume local. O que é moral (costume) em determinada região, pode não ser em outra localidade. $O$ homem, para merecer a confiança dos entes queridos dos amigos e dos profissionais de diversas atividades, tem que ser ético. É preciso viver dentro do respeito mútuo no lar, no trabalho e na sociedade. A ética se completa com a ordem moral.

Como cidadåo, o homem é obrigado a se comportar dentro de uma norma legăl. Nós, enquanto cidadåos, elegemos os nossos representantes junto aos poderes legalmente constituidos, a fim de que eles estabeleçam as normas legais que determinam os nossos direitos e obrigaçōes. Além da moral e da érica, temos que saber viver dentro da lei - só podemos fazer o que é legal, moral e ético. $O$ homem público (leia-se politico - nossos governantes) também nāo pode fugir deste tripé que dignifica o ser humano. Para que uma sociedade possa ser forte, ter a paz, viver a humanidade, enfim, ter uma vida feliz, é preciso que todos os membros de uma comunidade - governantes e governados - vivam dentro dos principios da moral, da ética e da legalidade, jamais esquecendo que acima de tudo e de todos existe o Criador - Deus. mTAKAO AOKI, ASSAI. 


\title{
Revista Veja - 09/08/1995
}

A história

resolvida por leis

\section{NOTAS INTERNACIONAIS}

\section{Guerra aos mendigos}

\begin{abstract}
A França encontrou um jeito de fazer com que os turistas não se sintam mais incomodados pelos mendigos: decidiu proibi-los. Os prefeilos de várias cidades turísticas recorreram a decretos municipais para proibir a mendicância. $\mathrm{O}$ ministro do Interior, Jean-Louis Debré, apoiou os prefeitos com uma circular que dá garantia jurídica à proibição de mendigar. Os

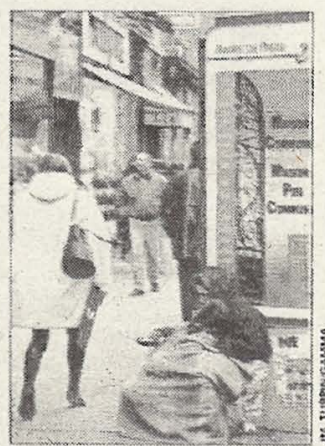

Mendiga muma rua de Paris mendigos podem até pedir esmola, disse Debré, mas não nas calçadas, centros comerciais e praças públicas - ou seja, em nenhum lugar onde haja gente. Só falta o governo usar a mesma receita para o problema dos 3,3 milhões de franceses desempregados.
\end{abstract}




\section{Medidas do plano de segurança do Governo FHC-2000}

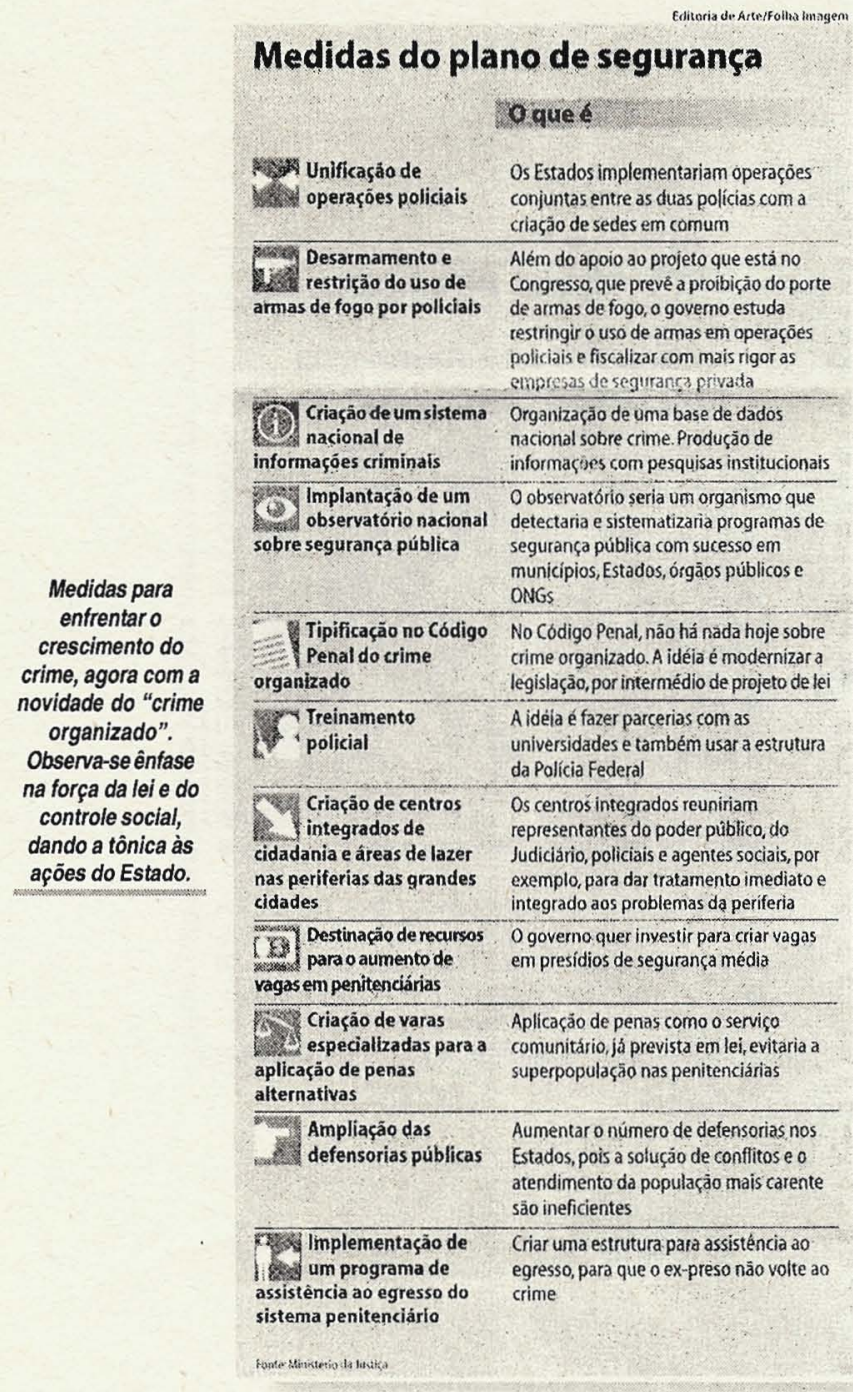

A história resolvida por leis 


\section{Gazeta do Povo - 01/05/2000}

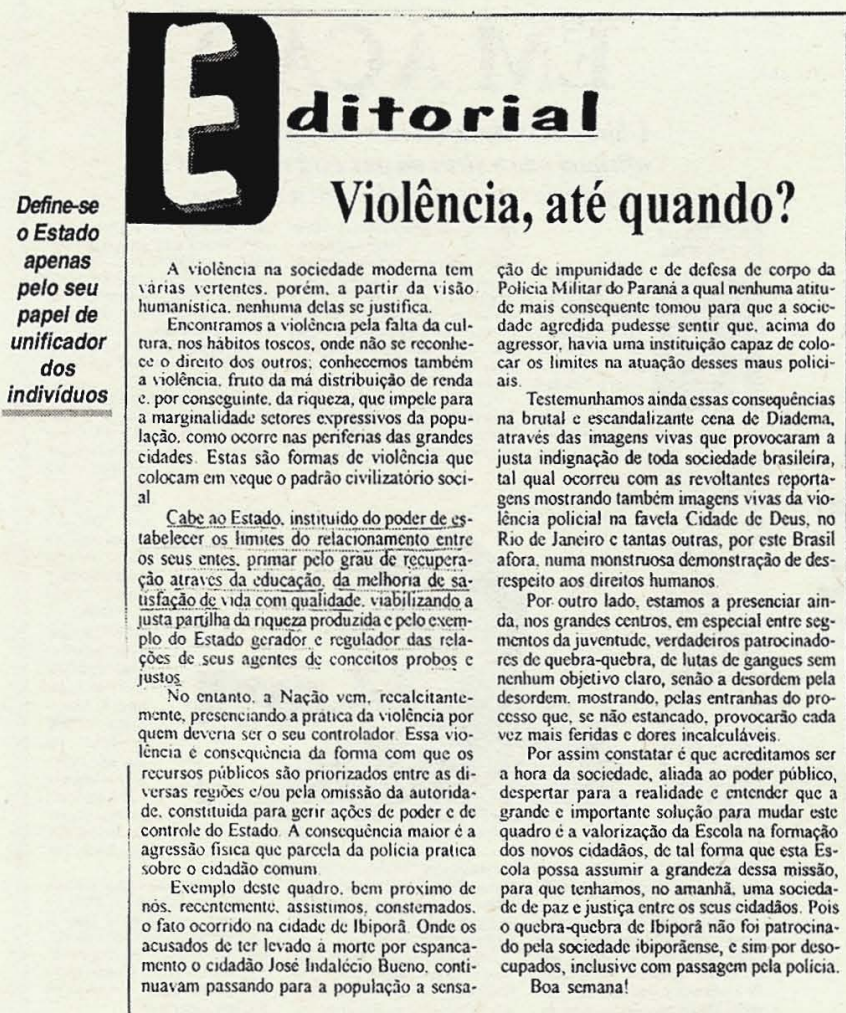

O papel

da escola

na

socialização

No inicio o texto associa a origem da violência às duas causas

(falta de cultura e má distribuição de renda), provavelmente, verdadeiras.

Mas, quando fala em soluções opta pelo privilegiamento da "questão da cultura", propondo a Escola como principal instituição regeneradora da situação.

Neste caso, por exemplo, o quebra-quebra de lbiporã torna-se obra de

"desocupados", desajustados, desviantes. 


\section{Destaque paraa função da solidariedade social, ligada à paz e à ordem.}
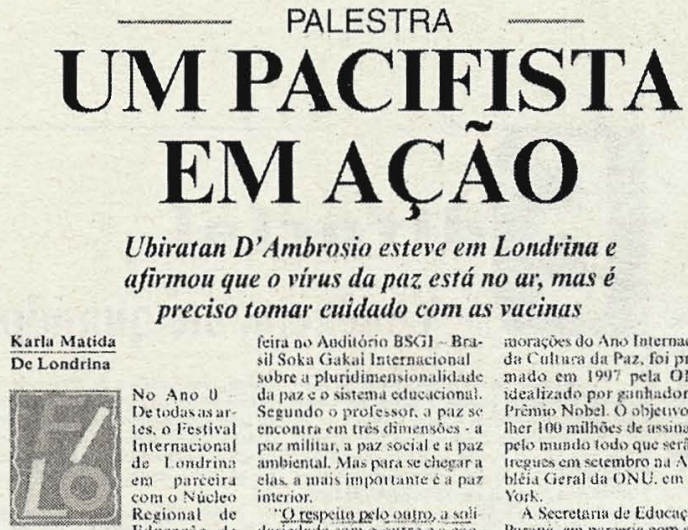

Ubiratan D'Ambrosio esteve em Londrina e afirmou que o vírus da paz está no a; mas é preciso tomar euidado com as vacinas

feira no Auditório BSCil - Bra- raoracóes do Ano Internacional sil Sola Gatkuilnternacionat sobre a pluridimensionaliclade da paz o o sistema educiciona? idealizado por peta ONL es

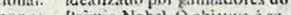

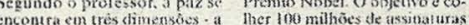
paz militar, a paz social e a paz pelo mundo todo que serâo cnambiental Mas para se cherar at Iregues em setembro ad Astemt-

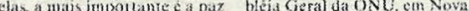
interior.

"O respeita pelo onem, a sali A Secretana de Edacacào do lariedade como outro e a con-. Parank, em parceria com a Uni-
Londrina trouse Euracación de paulista Ubiratan Ambrosio

re "Educs-

๘ุื้๋ parit a

Paz". Segun.

do a diretora

do Filo. o ab-

jecico do Festi.

val s mesmo

abranger to-

das as areas.

"A educiscão é

ama das bar-

deiras do

Festival", ex-

plicou Nitis.

que teve a

dueia de trazer

1) professor

Ubiratan

D'Ambrosio

para lundrina

apos ler o livro "Fudacasŭo prał: unza Socredade em Transição". do qual ele ce o autor.

Professor emerito de Matemática das lnicimp. pós-doutorado pela Brinin Cmisersity. dos Estados Lnidos. Ubiratan D A mbrosio é nembro do Conselbo Diretor do insrifule for fisformation Fe hnology in Educa* tora (IITE), da linesco, sediado ena Moscou (19980002). Além do livro citado por Nitis Jacon. o proficssor tambem escrevea "Temas Transzersais e Folucacào en: Valores Humanos", em co-autoria com Aaa Améha Inone e Reginas de Fituma Migliori.

Fin Londrina o professor mi. aistrou palestra na tiltima terça. peraçio com o outro sio os lris versidade federal e a Unesco pontos de una ctica maior e que isnçaram o Masifesto $2000 \mathrm{~cm}$ maxço doste ano. A intertpio e coletar dois milhoes de assinataras entre alunos. professores e pais por lodo - Fstado. A coleta de assinaturis no $\mathrm{Pa}$. riná segue utć o dia 26 de ju. nho. O Manifesto 2000 tatnhém foi lançado extra. oficialinente an Londrina no ano passado. pelo Colé. gio Universi-

conduz á paz" explicou es paics. trante. Para cle, cula eticas है a $\mathrm{ms}$. pusta para a tal pac interiot. "A suidariedade ć o nonto de parride piria maz social

Falando para uma platécia formada em sua maioria por pro. fessures da rede pública de crisi. no. D A nubrosio lembrou que *o curriculo rigido so thoss gronde inimigo. Femos que nos crutcle in ibertar do programa para da atencilo a cramya. O tixas e cla c o carriculo pode anxiliar.

A discussio wobic edicerctio e mudanyes no sistema cducicio nal propostas pelo profersor anrof tiada a questǎo do Manifesio 2000 - Por um culiura da $\mathrm{Paz}$ : da Nào-Violència. O manifesto que é parte das cume- tátio

Pafa o profesor tma inictati. 7a come o Marifesto 2no0 eo primeciso passo para 4 to racurde pura eproblem qu vio.

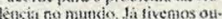

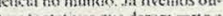
sio e contagiow. E o virus da kz yue esta no ar

Mas scyundo ele deve-se comar cuidado eoma vauna cuntra virus da pae que tei imi dus manearas de luta: contra a tai kacinas e a reformulacio do sisteme elucacional, que anda hoje irata o alano como se ele estiverse nu. ma estcira de produça em scnet. 